\section{Significance of Perfusate Lactic Acidosis in Cadaveric Renal Transplantation}

\author{
R. W. G. JOHNSON, MARILYN ANDERSON, \\ R. M. R. TAYLOR, JOHN SWINNEY
}

British Medical fournal, 1973, 1, 391-395

\begin{abstract}
Summary
Thirty-two human cadaver kidneys were assessed by continuous perfusion before transplantation. Altogether, 26 were transplanted. Ten kidneys functioned immediately, of which nine had excellent renal function at three months. Sixteen had delayed onset of function, of these only five had excellent function at three months. There was no difference in warm ischaemic interval between the two groups or in ice storage time. The immediate function group, however, were perfused for twice as long as the delayed function group. The two groups could not be separated on donor history, but they could be precisely separated during perfusion by measuring lactic acidosis and lactic acid dehydrogenase (LDH). The biggest single difference between the groups was in terms of donor preparation.
\end{abstract}

\section{Introduction}

The severity of ischaemic injury to which a human cadaveric kidney has been exposed is not usually apparent from the donor's history or from clinical assessment. Hypoxia is probably the principal cause of damage to such kidneys, and in the absence of oxygen the cells must produce energy by glycolysis which is associated with the production of a lactic acidosis (Chambers and Chambers, 1961).

Cellular swelling due to hypoxia (Leaf, 1956) has been implicated as a cause of increasing renal vascular resistance and also as a cause of breaches which have been seen in the cell membrane (Ashford and Burdette, 1965) through which cytoplasmic enzymes can leak (King et al., 1959). As time proceeds, the alterations in cell $\mathrm{pH}$ together with changes in chemical and osmotic homeostasis result in denaturation of the proteins of the dying cell. It follows then that measurement of changes in perfusate $\mathrm{pH}$ and lactate concentration should indicate the extent of the anoxic injury that a kidney has received.

In this study changes in the acid-base balance of the perfusate have been measured in an attempt to assess the condition of human cadaveric kidneys during continuous hypothermic perfusion before transplantation. The results have been correlated with the subsequent function of the kidneys after transplantation.

\footnotetext{
Department of Surgery, Royal Victoria Infirmary, Newcastle upon Tyne NE1 4LP

R. W. G. JOHNSON, M.B., F.R.C.s., Senior Registrar in Urology

MARILYN ANDERSON, F.I.L.T., Technical Âssistant

R. M. R. TAYLOR, CH.M., F.R.C.S., Consultant Surgeon in Vascular Surgery and Transplantation

JOHN SWINNEY, M.S., F.R.c.s., Professor of Urological Surgery and Director of Renal Transplantation Unit
}

\section{Materials and Methods}

\section{PERFUSION SYSTEM}

The apparatus has been described in detail elsewhere (Scott et al., 1969). It comprises a Perspex kidney chamber, a disc oxygenator, a Watson Marlow roller pump, and a cooling coil. The perfusing solution recirculates through polyvinyl chloride tubing. A filter, a manometer, a bubble trap, and a sampling tap are included in the circuit.

The temperature of the perfusate is kept at $6^{\circ} \mathrm{C}$. The flow rate is set at $1 \mathrm{ml} / \mathrm{g} / \mathrm{min}$ and only adjusted if the systolic pressure falls to $40 \mathrm{~mm} \mathrm{Hg}$ or below.

The oxygenator is gassed with a mixture of $98 \% \mathrm{O}_{2} 2 \% \mathrm{CO}_{2}$ which after a short period of stabilization gives a solution with a stable $\mathrm{PO}_{2}$ of $400-450 \mathrm{~mm} \mathrm{Hg}$, a $\mathrm{PCO}_{2}$ of $14 \pm 2 \mathrm{~mm} \mathrm{Hg}$, and a $\mathrm{pH}$ of $7 \cdot 3$.

The perfusion solution is human albumin $4.5 \mathrm{~g} / 100 \mathrm{ml}$ suspended in a modified physiological saline (table I). This solution $\mathrm{PPF}_{2}$ has been evaluated previously (Johnson et al., 1972).

TABLE I-Final Composition of $\mathrm{PPF}_{2}$

\begin{tabular}{|c|c|c|}
\hline Substance & & Range of Value in PPF, \\
\hline 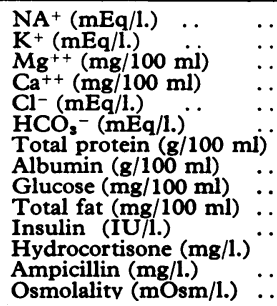 & 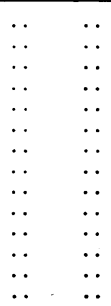 & $\begin{array}{c}125-135 \\
15-20 \\
5-7 \\
4 \cdot 4 \\
100-110 \\
25-30 \\
3 \cdot 4-4 \cdot 0 \\
3 \cdot 4-4 \cdot 0 \\
150 \\
10-15 \\
100 \\
250 \\
1,250 \\
275\end{array}$ \\
\hline
\end{tabular}

\section{PREPARATION OF THE KIDNEYS}

Kidneys collected in the Newcastle region for our own use are first flushed with cold $\mathrm{PPF}_{2}$ until they are uniformly pale in colour and the venous effluent is clear. They are then transported in ice from the donating hospital to the preservation laboratory.

Kidneys arriving from other centres have usually been flushed with either Collins $\mathrm{C}_{4}$ solution, or with dextran, fructose, and bicarbonate (Gelin). Such kidneys have usually been stored in ice for at least six hours before arrival. All kidneys arriving at the laboratory are placed on a sterile, ice-cooled tray, and are inspected and prepared for transplantation. When a separate polar artery is present it is our practice whenever possible to anastomose the smaller vessel to the side of the main renal artery with a continuous suture of $6 / 0$ Ethiflex. The renal artery is cannulated and connected to the perfusion circuit.

\section{METHODS OF ASSESSMENT}

Perfusion Pressure is read from a Sartorious manometer which has been adjusted to zero before the kidney is joined to the circuit. No adjustments to flow rate are made unless the pressure is falling.

Measurements of $\mathrm{pH}, \mathrm{PO}_{2}, \mathrm{PcO}_{2}$ are made on fresh samples of perfusate using an Astrup blood microsystem $\mathrm{BMS}_{2}$ (Radiometer, Copenhagen). This gives a rapid digital read-out to three places of decimals, corrected to $37^{\circ} \mathrm{C}$, and for humidity and atmospheric pressure. The perfusate is allowed to equilibrate to a stable $\mathrm{pH}$ of 7.3 before connecting the kidney. 
Lactate is measured on fresh samples using a Boehringer lactate ultraviolet test combination 15972 T.L.A.A.

Lactic acid dehydrogenase (LDH) is measured on fresh samples of perfusate using a Boehringer T.Lac test kit combination. There was a wide variation in the duration of the perfusion. Therefore, repeated readings had to be taken throughout, so that it was possible to compare the initial readings and the values after 60 minutes with the most extreme values, and with those at the end of the perfusion.

\section{ASSESSMENT OF PATIENTS}

Patients receiving kidneys assessed by these criteria were divided into two groups, depending on whether they did or did not need dialysis in the post-transplant period. Thereafter, renal function was assessed by estimation of creatinine clearance. When a transplanted kidney failed because of rejection proved histologically it has been eliminated from the study, except where indicated by an asterisk in tables II and III.

TABLE II-Preservation Characteristics of the 10 Group 1 Kidneys that Functioned Immediately After Transplantation

\begin{tabular}{|c|c|c|c|c|c|c|c|c|}
\hline \multirow{2}{*}{ Recipient } & \multirow{2}{*}{$\begin{array}{l}\text { Ante- } \\
\text { mortem } \\
\text { Hypo- } \\
\text { tension } \\
\text { (mins) }\end{array}$} & \multirow{2}{*}{$\begin{array}{c}\text { Warm } \\
\text { Ischae- } \\
\text { mia } \\
\text { Time } \\
\text { (mins) }\end{array}$} & \multirow{2}{*}{$\begin{array}{c}\text { Ice } \\
\text { Storage } \\
\text { Time } \\
\text { (mins) }\end{array}$} & \multirow{2}{*}{$\begin{array}{c}\text { Perfusion } \\
\text { Storage } \\
\text { Time } \\
\text { (mins) }\end{array}$} & \multirow{2}{*}{$\begin{array}{c}\text { Total } \\
\text { Storage } \\
\text { Time } \\
\text { (mins) }\end{array}$} & \multicolumn{3}{|c|}{$\begin{array}{c}\text { Clinical Result } \\
\text { (Creatinine Clearance) }\end{array}$} \\
\hline & & & & & & $\begin{array}{l}24 \mathrm{hr} \\
(\mathrm{ml} / \\
\mathrm{min})\end{array}$ & $\begin{array}{l}1 \text { wk. } \\
\text { (ml/ } \\
\text { min) }\end{array}$ & $\begin{array}{c}3 \mathrm{mths} \\
(\mathrm{ml} / \\
\mathrm{min})\end{array}$ \\
\hline $\begin{array}{l}\text { SWE } \\
715898 \\
733412 \\
763534 \\
719069 \\
708275 \\
794573 \\
700290 \\
830997 \\
728878\end{array}$ & $\begin{array}{l}\text { nil } \\
\text { nil } \\
\text { nil } \\
\text { nil } \\
\text { nil } \\
\text { nil } \\
\text { nil } \\
\text { nil } \\
\text { nil } \\
\text { nil }\end{array}$ & $\begin{array}{r}2 \\
25 \\
10 \\
30 \\
35 \\
2 \\
15 \\
18 \\
15 \\
20\end{array}$ & $\begin{array}{l}360 \\
30 \\
600 \\
420 \\
300 \\
360 \\
420 \\
120 \\
270 \\
360\end{array}$ & $\begin{array}{r}660 \\
1,260 \\
600 \\
780 \\
600 \\
180 \\
180 \\
270 \\
480 \\
660\end{array}$ & $\begin{array}{r}1,020 \\
1,290 \\
1,200 \\
1,200 \\
900 \\
540 \\
600 \\
390 \\
750 \\
1,020\end{array}$ & $\begin{array}{r}30 \\
5 \\
35 \\
15 \\
20 \\
25 \\
5 \\
10 \\
10 \\
7 \cdot 5\end{array}$ & $\begin{array}{l}55 \\
35 \\
40^{*} \\
45 \\
35 \\
4^{*} \\
15- \\
30 \\
45 \\
35\end{array}$ & $\begin{array}{l}65 \\
61.5 \\
\text { Dialysis } \\
54 \cdot 5 \\
115.5 \\
50 \\
102.9 \\
51.7 \\
75 \\
82.2\end{array}$ \\
\hline $\begin{array}{l}\text { Mean } \pm \\
\text { S.D. }\end{array}$ & nil & $\begin{array}{l}17 \cdot 2 \pm \\
10 \cdot 92\end{array}$ & $\begin{array}{l}324 \pm \\
159 \cdot 9\end{array}$ & $\begin{array}{l}567 \pm \\
323 \cdot 2\end{array}$ & $\begin{array}{l}891 \pm \\
309 \cdot 53\end{array}$ & & & \\
\hline
\end{tabular}

* Indicates acute episodes of rejection proved histologically.

TABLE III-Preservation Characteristics of the 16 Group 2 Kidneys that did not Function Immediately

\begin{tabular}{|c|c|c|c|c|c|c|c|c|}
\hline \multirow{2}{*}{ Recipient } & \multirow{2}{*}{$\begin{array}{l}\text { Ante- } \\
\text { mortem } \\
\text { Hypo- } \\
\text { tension } \\
\text { (mins) }\end{array}$} & \multirow{2}{*}{$\begin{array}{c}\text { Warm } \\
\text { Ischae- } \\
\text { mia } \\
\text { Time } \\
\text { (mins) }\end{array}$} & \multirow{2}{*}{$\begin{array}{c}\text { Ice } \\
\text { Storage } \\
\text { Time } \\
\text { (mins) }\end{array}$} & \multirow{2}{*}{$\begin{array}{c}\text { Perfusion } \\
\text { Storage } \\
\text { Time } \\
\text { mins) }\end{array}$} & \multirow{2}{*}{$\begin{array}{c}\text { Total } \\
\text { Storage } \\
\text { Time } \\
\text { (mins) }\end{array}$} & \multicolumn{3}{|c|}{$\begin{array}{l}\text { Clinical Result } \\
\text { (Creatinine Clearance) }\end{array}$} \\
\hline & & & & & & $\begin{array}{l}24 \mathrm{hr} \\
\text { (ml/ } \\
\mathrm{min})\end{array}$ & $\begin{array}{l}1 \mathrm{wk} . \\
\text { (mi/ } \\
\mathrm{min} \text { ) }\end{array}$ & $\begin{array}{l}3 \mathrm{mths} \\
(\mathrm{ml} / \\
\mathrm{min})\end{array}$ \\
\hline $\begin{array}{l}810385 \\
798534 \\
706491 \\
659061 \\
733795 \\
798466 \\
656781 \\
700806\end{array}$ & $\begin{array}{c}180 \\
65 \\
\text { nil } \\
120 \\
? \\
240 \\
\text { nil } \\
120 \\
\text { nil }\end{array}$ & $\begin{array}{l}15 \\
12 \\
11 \\
20 \\
18 \\
28 \\
55 \\
20\end{array}$ & $\begin{array}{r}10 \\
20 \\
30 \\
300 \\
270 \\
140 \\
240 \\
300 \\
20\end{array}$ & $\begin{array}{l}205 \\
180 \\
225 \\
120 \\
135 \\
270 \\
120 \\
420 \\
660\end{array}$ & $\begin{array}{l}215 \\
200 \\
255 \\
420 \\
405 \\
410 \\
360 \\
720 \\
680\end{array}$ & $\begin{array}{l}\text { zero } \\
\text { zero } \\
\text { zero } \\
\text { zero } \\
\text { zero } \\
\text { zero } \\
\text { zero } \\
\text { zero } \\
\text { zero }\end{array}$ & $\begin{array}{c}\text { zero } \\
11 \cdot 0 \\
9 \cdot 0^{*} \\
15 \cdot 0 \\
17 \cdot 5 \\
\text { Graft } \\
\text { zero* } \\
11 \cdot 0^{*} \\
\text { zero }\end{array}$ & $\begin{array}{c}\text { Dialysis } \\
69 \cdot 2 \\
40 \cdot 1 * \\
\text { Dialysis } \\
\text { Dialysis } \\
\text { removed } \\
42^{*} \\
18.5 \\
52.5\end{array}$ \\
\hline $\begin{array}{l}618025 \\
803821 \\
724679\end{array}$ & $\begin{array}{c}\text { nil } \\
120 \\
45 \\
\text { nil } \\
240 \\
65 \\
?\end{array}$ & $\begin{array}{l}20 \\
22 \\
30 \\
35 \\
15 \\
20 \\
26\end{array}$ & $\begin{array}{r}240 \\
35 \\
200 \\
470 \\
360 \\
300 \\
410\end{array}$ & $\begin{array}{l}170 \\
170 \\
250 \\
360 \\
180 \\
120 \\
195 \\
180\end{array}$ & $\begin{array}{l}400 \\
410 \\
285 \\
560 \\
650 \\
480 \\
495 \\
590\end{array}$ & $\begin{array}{l}\text { zero } \\
\text { zero } \\
\text { zero } \\
\text { zero } \\
\text { zero } \\
\text { zero } \\
\text { zero }\end{array}$ & $\begin{array}{c}2 \mathrm{4ro} \\
\text { Graft } \\
9 \cdot 0 \\
9.0 * \\
\text { zero } \\
\text { zero } \\
\text { zero }\end{array}$ & 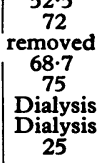 \\
\hline $\begin{array}{l}\text { Mean } \pm \\
\text { S.D. }\end{array}$ & & $\begin{array}{l}22 \cdot 625 \pm \\
10 \cdot 86\end{array}$ & $\begin{array}{l}206 \cdot 8 \pm \\
150 \cdot 3\end{array}$ & $\begin{array}{l}236 \cdot 9 \\
140 \cdot 8\end{array}$ & $\begin{array}{l}443 \cdot 7 \pm \\
162 \cdot 75\end{array}$ & 443.7 & & \\
\hline
\end{tabular}

* Indicates rejection

\section{Results}

Thirty-two human cadaver kidneys were assessed before transplantation. The kidneys were placed in two groups (tables II and III). Group 1 contained those kidneys which functioned immediately and group 2 contained those kidneys which failed to function immediately - that is, the recipient required at least one dialysis in the immediate postoperative period. A third group was added (table IV) containing those kidneys which were not transplanted because of high or rising perfusion pressure.
TABLE IV-Preservation Characteristics of Group 3 Kidneys Excluded on Grounds of Rising Perfusion Pressure

\begin{tabular}{|c|c|c|c|c|c|c|c|c|}
\hline \multirow{2}{*}{$\begin{array}{l}\text { Donor } \\
\text { Source }\end{array}$} & \multirow{2}{*}{$\begin{array}{c}\text { Warm } \\
\text { Ischae- } \\
\text { mia } \\
\text { Time } \\
\text { (min) }\end{array}$} & \multirow{2}{*}{$\begin{array}{l}\text { Ice } \\
\text { Storage } \\
\text { Time } \\
\text { (min) }\end{array}$} & \multirow{2}{*}{$\begin{array}{c}\text { Per- } \\
\text { Perfusion } \\
\text { Time } \\
\text { (min) }\end{array}$} & \multirow{2}{*}{$\begin{array}{l}\text { Total } \\
\text { Storage } \\
\text { Time } \\
\text { (min) }\end{array}$} & \multirow{2}{*}{ Comments } & \multicolumn{3}{|c|}{$\begin{array}{l}\text { Perfusion Pressure } \\
(\mathrm{mm} \mathrm{Hg})\end{array}$} \\
\hline & & & & & & Initial & $60 \mathrm{~min}$ & Final \\
\hline B & 20 & $300^{*}$ & 1,440 & 1,740 & $\begin{array}{l}35 \text { min } \\
\text { extra } \\
\text { cardiac } \\
\text { massage }\end{array}$ & 40 & 95 & 120 \\
\hline $\begin{array}{l}\text { NGH } \\
\text { NGH } \\
\text { L }\end{array}$ & $\begin{array}{l}15 \\
25 \\
22\end{array}$ & $\begin{array}{r}65 \dagger \\
65 \dagger \\
260 \dagger\end{array}$ & $\begin{array}{c}1,440 \\
1,400 \\
120\end{array}$ & $\left.\begin{array}{c}1,505 \\
1,465 \\
380\end{array}\right\}$ & $\begin{array}{l}6 \text { hours } \\
\text { hypotension } \\
\text { Poor }\end{array}$ & $\left\{\begin{array}{l}120 \\
120 \\
100\end{array}\right.$ & $\begin{array}{l}100 \\
100 \\
110\end{array}$ & $\begin{array}{r}130 \\
90 \\
120\end{array}$ \\
\hline $\mathbf{S}$ & 27 & $240^{*}$ & 660 & 900 & Poor wash- & 40 & 110 & 80 \\
\hline Lo & 32 & $515^{*}$ & 600 & 1,115 & $\begin{array}{l}\text { out, blotchy } \\
\text { Poor wash- } \\
\text { out, } \\
\text { atheroma }\end{array}$ & 60 & 60 & 75 \\
\hline Range & $15-32$ & $65-515$ & $120-$ & $\begin{array}{l}380- \\
1,740\end{array}$ & & $\begin{array}{l}40- \\
120\end{array}$ & $60-$ & $\begin{array}{r}75- \\
130\end{array}$ \\
\hline
\end{tabular}

Washout solutions were:

* Rheomacrodex, fructose, bicarbonate (Gelin).
† C، (Collins).

Function after Transplantation.-Of the 10 kidneys in group 1, nine had excellent renal function at three months, and one graft had to be removed because of uncontrollable rejection. In group 2 only five out of 16 kidneys had excellent function at three months (tables II and III). Seven patients were back on dialysis and the remaining four had creatinine clearances of less than $50 \mathrm{ml} / \mathrm{min}$. The difference between groups 1 and 2 was highly significant $\left(\chi^{2}=8.5467, P<0.001\right)$.

Preservation Characteristics.-Group 1 kidneys spent a mean $324 \pm 159.9$ (S.D.) minutes in ice. This did not differ significantly from group 2 where the mean ice storage time was $206 \cdot 8 \pm 150.3 \mathrm{~min}(\mathrm{P}>0.05)$.

Group 1 kidneys were, however, perfused for much longer than group 2. The mean difference was $330 \cdot 1 \min (t=3 \cdot 6$, $0.01>P>0.001)$. Group 1 kidneys necessarily had longer total storage times; the mean difference was $447.3 \mathrm{~min}(t=4 \cdot 8$, $\mathrm{P}<0.0001$ ) (table V).

Injury Factors.- There was no significant difference in warm ischaemic interval between the two groups; the mean difference was $5.4 \mathrm{~min}(t=1.23,0.5>\mathrm{P}>0.3)$. There was, however, a significant difference in the occurrence of antemortem hypotension. None of the group 1 kidneys had any history of antemortem hypotension, whereas the donors of nine of the group 2

TABLE V-Summary of Relevant Mean Storage Intervals ( \pm S.D.)

\begin{tabular}{|c|c|c|c|}
\hline & $\begin{array}{l}\text { Group 1 } \\
(\mathbf{n}=10)\end{array}$ & $\begin{array}{l}\text { Group 2 } \\
(\mathbf{n}=16)\end{array}$ & $\stackrel{t}{t}$ \\
\hline $\begin{array}{l}\text { Mean warm } \\
\text { ischaemia time } \\
\text { (min) }\end{array}$ & $17 \cdot 2 \pm 10 \cdot 92$ & $22 \cdot 625 \pm 10 \cdot 86$ & $\begin{array}{c}\text { d } 5.4 \\
t 1.23 \\
0.5>P>0.3\end{array}$ \\
\hline $\begin{array}{l}\text { Mean ice } \\
\text { storage time } \\
\text { (min) }\end{array}$ & $324: \pm 159 \cdot 9$ & $206 \cdot 8 \pm 150 \cdot 3$ & $\begin{array}{c}\mathrm{d} 117.2 \\
t 1.88 \\
0.1>\mathrm{P}>0.05\end{array}$ \\
\hline $\begin{array}{l}\text { Mean perfusion } \\
\text { storage time } \\
\text { (min) }\end{array}$ & $567 \pm 323 \cdot 2$ & $236 \cdot 9 \pm 140 \cdot 8$ & $\begin{array}{c}\text { d } 330.1 \\
t 3.6 \\
0.01>P>0.001\end{array}$ \\
\hline $\begin{array}{l}\text { Mean total } \\
\text { storage time } \\
\text { (min) }\end{array}$ & $891 \pm 309 \cdot 5$ & $443 \cdot 7 \pm 162 \cdot 8$ & \begin{aligned} & $\mathrm{d} 447.3 \\
t & \multicolumn{1}{c}{4.8} \\
\mathrm{P}<0.0001 & \end{aligned}$ \\
\hline
\end{tabular}

$\mathrm{d}=$ Mean difference.

TABLE VI-Summary of Injury Factors

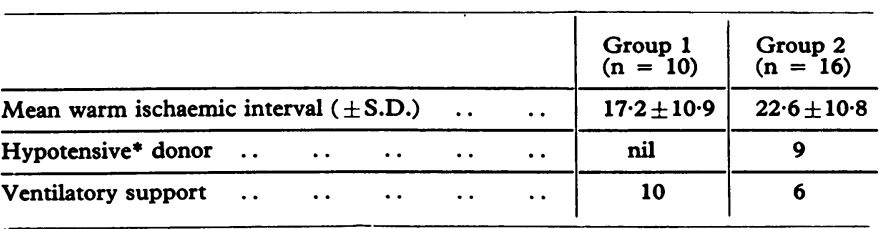

* Systolic B.P. $<100 \mathrm{~mm} \mathrm{Hg}$ for $>60 \mathrm{~min}$. 
kidneys had systolic blood pressures of less than $100 \mathrm{~mm} \mathrm{Hg}$ for more than one hour in the agonal period (table VI). No details were available for a further two in this group. All the group 1 kidneys were collected from donors on whom an elective ventilator switch off was performed. Only six of the 16 group 2 donors were ventilated.

\section{PERFUSION RESULTS}

Perfusion Pressure.-Five kidneys had perfusion pressures of $100 \mathrm{~mm} \mathrm{Hg}$ or more at the end of one hour's perfusion; flow rates were minimal for each kidney's weight (table IV). None of these kidneys was transplanted but the perfusion was continued up to 24 hours so that the perfusion characteristics could be measured and compared with the other two groups. Group 1 and group 2 kidneys all perfused without rising pressure. Mean systolic pressure for the two groups was $60 \pm 5 \mathrm{~mm} \mathrm{Hg}$ with a minimum flow rate of $1 \mathrm{ml} / \mathrm{g} / \mathrm{min}$. One kidney (included in group 3) was not transplanted despite a favourable pressure/ flow ratio because it was badly discoloured and had a very atheromatous artery.

Changes in Perfusate $p H$.- There was no difference in the initial perfusate $\mathrm{pH}$ between the three groups (figs. 1,2 , and 3 ). Mean value for the controls was $7 \cdot 328 \pm 0.05$. As soon as the kidney was placed in the circuit there was a fall in $\mathrm{pH}$. This fall was most profound in groups 2 and 3 . There was a highly significant difference in pH values between group 1 kidneys and

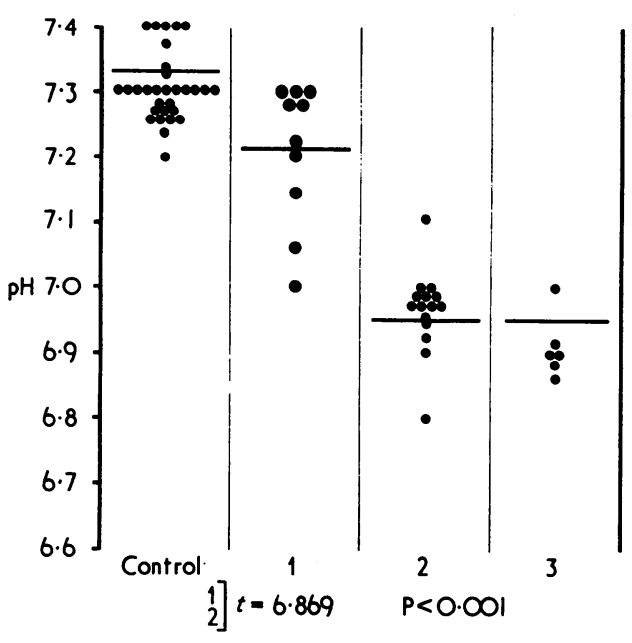

FIG 1-Comparison of perfusate pH values after 60 minutes of perfusion.

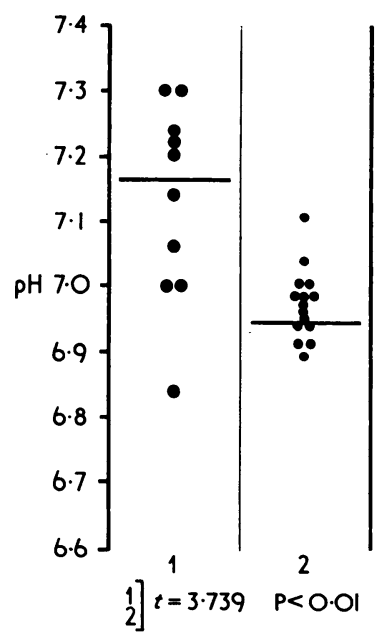

FIG. 2 -Comparison of the lowest $\mathrm{pH}$ values during perfusion.

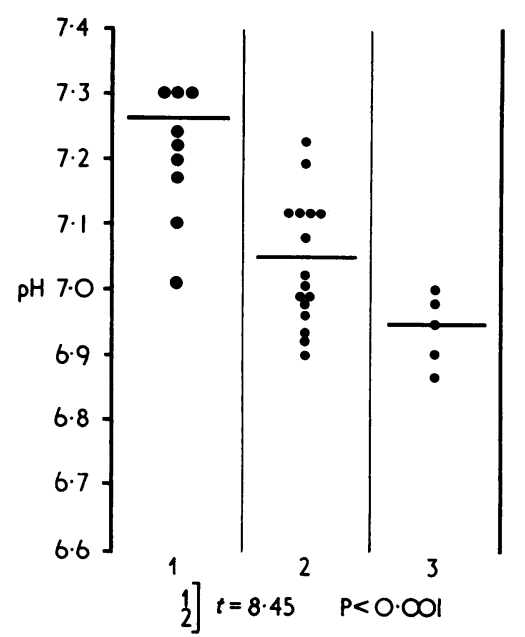

FIG. 3-Comparison of $\mathrm{pH}$ values at the end of perfusion.

kidneys from the other two groups at 60 minutes, and at the end of the perfusion period it was $P<0.001$ for both readings. The difference between groups 1 and 2 remained significant even when the lowest values were compared, $\mathrm{P}<0.01$.

Changes in Perfusate $\mathrm{PCO}_{2}$. - The mean $\mathrm{PcO}_{2}$ for $\mathrm{PPF}_{2}$, corrected for humidity and barometric pressure, was $13.9 \pm 1.73$ $\mathrm{mm} \mathrm{Hg}$. There was always an immediate rise in $\mathrm{PCO}_{2}$ when the kidney was placed in circuit, and there were highly significant differences in $\mathrm{PCO}_{2}$ between group 1 (mean $20.1 \pm 1.6 \mathrm{~mm} \mathrm{Hg}$ ) and groups 2 and 3 (means $32.6 \pm 2.5 \mathrm{~mm} \mathrm{Hg}$ and $30.48 \pm 4.8$ $\mathrm{mm} \mathrm{Hg}$ respectively). These differences were significant at 60 minutes $(P<0.0001)$ and at the end of perfusion $(P<0.0001)$ (fig.4). The rise in $\mathrm{PCO}_{2}$ reached its maximum after about an hour, thereafter it fell in group 1 to $18.7 \pm 1.82 \mathrm{~mm} \mathrm{Hg}$ and in group 2 to $28.5 \pm 1.66 \mathrm{~mm} \mathrm{Hg}$.

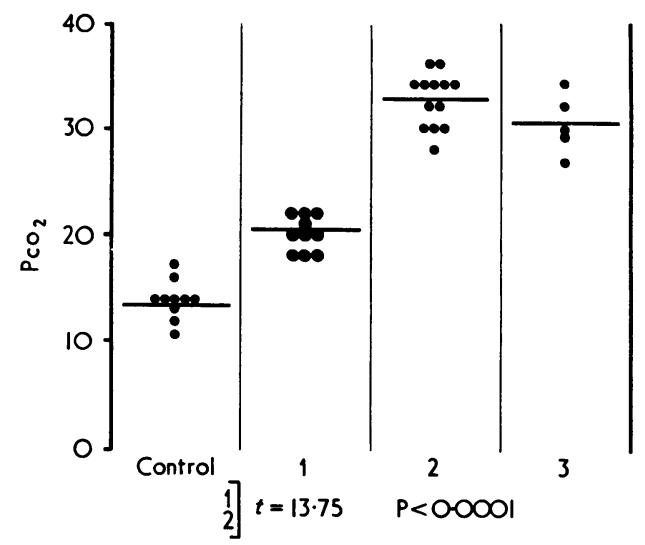

FIG. 4-Comparison of $\mathrm{PCO}_{2}$ difference during perfusion.

Change in Perfusate Lactate (Volume of perfusate $=350 \mathrm{ml}$ ). $-\mathrm{PPF}_{2}$ at $6^{\circ} \mathrm{C}$ contains very little lactate, mean $5.4 \pm 0.5 \mathrm{mg} / 100$ $\mathrm{ml}$. An immediate rise in lactate concentration occurred when a kidney was placed in the circuit, and the maximum rise always occurred within the first hour; group 1 to $29.6 \pm 5.58 \mathrm{mg} / 100$ $\mathrm{ml}$, group 2 to $60 \cdot 2 \pm 5 \cdot 8 \mathrm{mg} / 100 \mathrm{ml}$. The difference between the two groups at one hour was highly significant $(t=12 \cdot 29$, $P<0.0001)$. After the first hour the lactate concentration continued to increase, but at a very low rate. Mean lactate concentrations at the end of perfusion were: group $132 \pm 5.67 \mathrm{mg} / 100$ $\mathrm{ml}$, group $261 \cdot 14 \pm 4.48 \mathrm{mg} / 100 \mathrm{ml}$, and group $363.2 \pm 4 \cdot 8$ $\mathrm{mg} / 100 \mathrm{ml}$. The difference between group 1 and the other two groups was again significant ( $t=14.07, \mathrm{P}<0.0001$ ) (fig. 5).

Relation between $\mathrm{pH}, \mathrm{PCO}_{2}$, and Lactate in the Perfusate.When the maximum lactate concentration for each kidney is 


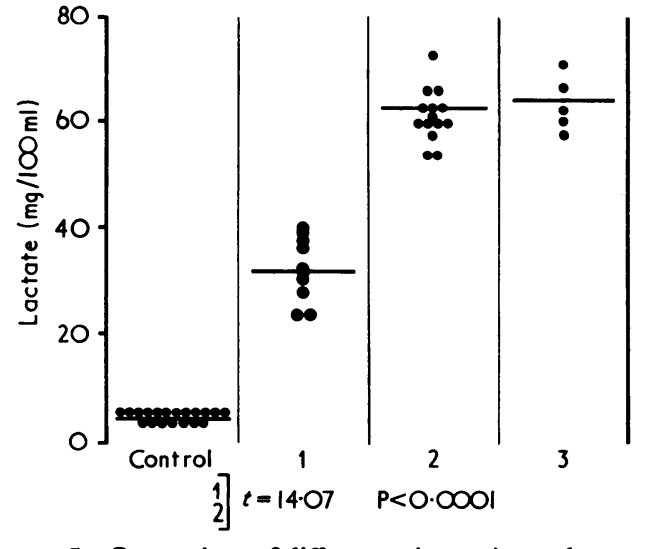

FIG. 5-Comparison of differences in maximum lactate concentration during perfusion.

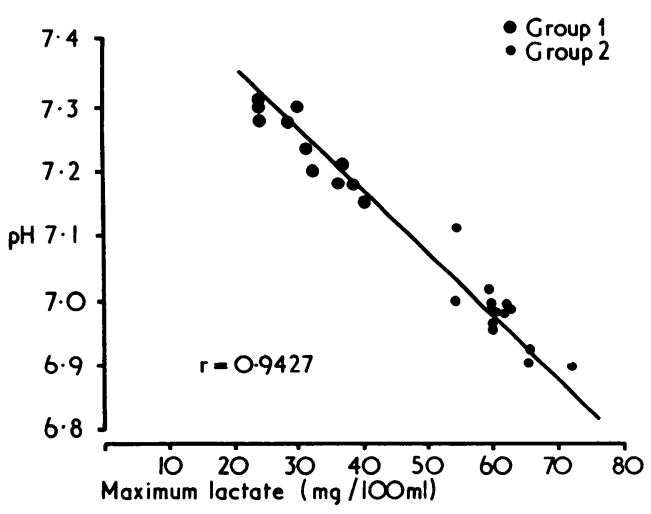

FIG. 6-Graph of maximum lactate concentration against $\mathrm{pH}$

plotted against its $\mathrm{pH}$ at 60 minites the relation is linear (fig. 6) with a correlation coefficient of 0.9427 . Two quite separate groups of kidneys can be seen. These groups coincide precisely with our functional groups 1 and 2 . Group 1 kidneys occupy the upper end of the line and group 2 kidneys the lower end.

In fig. 7 it can be seen that the relation betweem the maximum perfusate $\mathrm{PCO}_{2}$ for each kidney and its respective $\mathrm{pH}$ at 60 minutes is similar to that of lactate, with a correlation coefficient of 0.9211 , but the groups of kidneys do not separate so precisely on this line.

Change in Perfusate LDH.- Very high values of LDH were found in all three groups and the scatter of values was very wide (fig. 8). Nevertheless there was a statistically significant difference between group 1 and group 2, and group 2 and group 3, $P<0.0001$ in each instance.

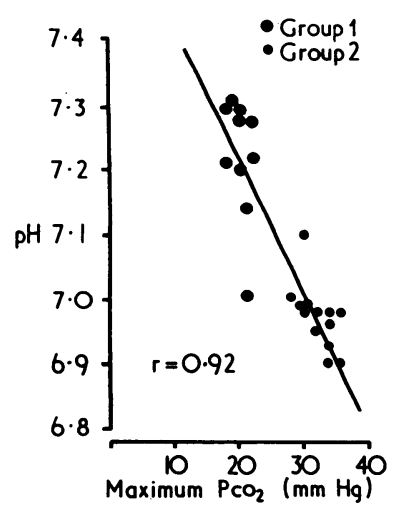

FIG. 7-Graph of maximum $\mathrm{PCO}_{2}$ against $\mathrm{pH}$.

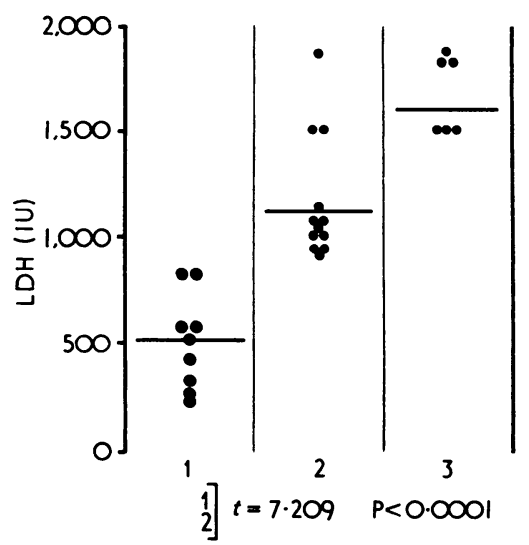

FIG. 8-Comparison of lactic acid dehydrogenase (LDH) concentration during perfusion.

\section{Discussion}

Two distinct types of kidney have been identified in this study: "neutral" kidneys (group 1) where $\mathrm{pH}$ remained stable and there was only a small initial increase in perfusate $\mathrm{PCO}_{2}$ and lactate; and "acid" kidneys (groups 2 and 3 ) which exhibited a profound fall in $\mathrm{pH}$ accompanied by a very significant increase in initial perfusate $\mathrm{PCO}_{2}$ and lactate. Group 1 kidneys functioned immediately and had excellent renal function at three months, whereas group 2 kidneys did not function immediately and only five out of 16 had good function at three months. Group 3 kidneys perfused with high and increasing vascular resistance and so were not thought suitable for transplantation.

We believe that the acidosis found during the early part of perfusion is a clear indication of anoxic injury suffered by the kidney before cooling.

A rapid fall in the surface $\mathrm{pH}$ of rabbit kidneys has previously been shown to occur when the renal artery is clamped (Dmochowski et al., 1966). This fall in $\mathrm{pH}$ is reduced when the kidney is rapidly cooled; in fact, the surface $\mathrm{pH}$ of rabbit kidneys varies inversely with temperature (Couch et al., 1967).

The measurement of $\mathrm{pH}$ changes in biological salines is more difficult to interpret since the changes in hydrogen ion activity are of very small order and are necessarily influenced by the dissociation constants of the buffers present.* The degree of change in perfusate $\mathrm{pH}$ for any one kidney will, therefore, vary from perfusion to perfusion and depends on the composition of the perfusion solution used. The actual value of the $\mathrm{pH}$ will also depend on the temperature at which the kidney is perfused.

In this perfusion system bicarbonate is the principal buffer with a $\mathrm{pK}$ of $6 \cdot 1$. Small additions of acid to the perfusate will, therefore, produce relatively large changes in $\mathrm{pH}$. In similar circumstances the presence of a phosphate buffer with a $\mathrm{pK}$ of 6.8 would have greatly reduced the change in $\mathrm{pH}$. It should be noted that group 2 kidneys were perfused only until a noticeable fall in $\mathrm{pH}$ occurred, so that it is unlikely that they suffered any further injury during perfusion.

The results of this study in terms of $\mathrm{pH}$ alone are applicable only to perfusion systems using a bicarbonate buffer, and the measurement of $\mathrm{pH}$ alone was of only limited clinical value; where $\mathrm{pH}$ remained stable between $7 \cdot 2$ and $7 \cdot 4$ it was safe to continue storage up to 24 hours. Whereas when perfusate pH fall rapidly to below $7 \cdot 0$ in the first hour it indicated that total storage time should be kept to a minimum. $\mathrm{pH}$ values between these two extremes defied interpretation when taken by themselves.

Fall in $\mathrm{pH}$ was accompanied by a proportional rise in $\mathrm{PCO}_{2}$ and lactate. The relation of each of these two factors to $\mathrm{pH}$ was linear with highly significant correlation coefficients. The

${ }^{*} \mathrm{pH}=\mathrm{pK}+\log \frac{(\text { salt })^{-}}{(\mathrm{acid})^{+}}$where $\mathrm{K}$ is the dissociation constant. 
differences between group 1 and groups 2 and 3 were highly significant for both $\mathrm{PCO}_{2}$ and lactate.

Furthermore, the differences were apparent in the first hour of perfusion and certainly reflected the degree of lactic acidosis which the kidney had developed before cooling.

The position of any given kidney in relation to the regression line of perfusate $\mathrm{pH}$ against lactate is a precise indication of that kidney's chance of functioning immediately and of having reasonable function three months after transplantation.

It was of particular interest to note that the perfusion characteristics of group 3 kidneys closely paralleled those of group 2 in terms of $\mathrm{pH}, \mathrm{PCO}_{2}$, and lactate.

There was also a high degree of correlation between the severity of lactic acidosis and the accumulation of LDH in the perfusate. Since $\mathrm{LDH}$ is present in large quantities in the cytoplasm of renal tubular cells, a rise in LDH should indicate the extent of renal tubular injury. LDH accumulated progressively throughout perfusion and there was overlap between the groups. The release of enzymes by injured cells does not follow a uniform pattern and when low may reflect patchy areas of injury or poorly distributed perfusate.

The injury process shown by this study appears to have occurred most often in the agonal period since there was no significant difference in warm ischaemic interval between the groups. Neither was there any significant difference in ice storage between the groups. Paradoxically, group 1 kidneys had the longest total storage times; this was because prolonged periods of perfusion were regarded as safe by virtue of a stable $\mathrm{pH}$.

The antemortem injury was usually due to a prolonged agonal period with either hypotension or a long interval between ventilatory and circulatory arrest. The ventilatory support which all the group 1 donors received appears to have reduced signifi- cantly the risk of injury. The injury process was usually subtle and apparently not significant from donor history. Most of the kidneys washed out rapidly and uniformly, confirmed by their subsequent lack of resistance to perfusion. It was only by perfusing the kidney and correlating changes in $\mathrm{pH}$ and lactate and $\mathrm{PCO}_{2}$ that differences between them could be distinguished. It may be that continuous perfusion will have its greatest application as a method of assessing kidneys before transplantation.

Throughout this study we have received valuable help from members of the artificial kidney unit at the Royal Victoria Infirmary, particularly Professor D. N. S. Kerr and Dr. P. R. Uldall. We also received valuable information and technical criticism from members of the department of physiology and in particular Professor F. L. Blair, Dr. David Reed, and Dr. H. Lake.

The tables and figures were prepared by Miss Barbara James, and the manuscript was typed by Mrs. Anne Feeley.

This work was supported by the Northern Counties Kidney Research Fund and the Newcastle upon Tyne Regional Hospital Board.

\section{References}

Ashford, T. P., and Burdette, W. M. (1965). Annals of Surgery, 162, 191.
Chambers, R., and Chambers, E. (1961). Explorations into the Nature of the ambers, R., and Chambers, E. (1961). Explorations into the

Living Cell. Cambridge, Mass., Harvard University Press.
Couch, N. P., Maginn, R. R., Middleton, M. K., Appleton, D. R., and Dmochowski, J. R. (1967)., Surgery, Gynecology and Obstetrics, 125, 521 . Dmochowski, J. R., Couch, N. P., Kempf, R. A., and Appleton, D. R. (1966). Fournal of Surgical Research, 6, 45.

Johnson, R. W. G., et al. (1972). Transplantation, 13, 270.

King, D. W., Paulson, S. R., Hannaford, N. C., and Krebs, A. T. (1959). American fournal of Pathology, 35, 369 .

Leaf, A. (1956). Biochemical fournal, 62, 241.

Scott, D. J., Morley, A., and Swinney, J. (1969). British fournal of Surgery, 56, 688 .

\section{MEDICAL MEMORANDA}

\section{Iatrogenic Rupture of the Spleen}

\section{A. J. MEARNS}

British Medical fournal, 1973, 1, 395-396

The hazards of pleural biopsy and aspiration are well known, but there is little documentation of splenic injury after these procedures. Shepherd $(1960,1968)$, in an extensive review of the literature of trauma to the spleen, makes no reference to this type of injury. In a series of 308 splenectomies (Slate et al., 1969) 108 were performed as a result of iatrogenic injury, but none were the result of chest aspiration or pleural biopsy.

Textbooks recognize the risk of splenic injury during such procedures (Davis, 1967), and although serious damage is rare the spleen may sustain many minor subcapsular injuries.

Three cases were recorded during a period of seven years in the Liverpool Regional Thoracic Surgical Centre and they illustrate the presentation of such injury and the difficulties of its diagnosis.

Hammersmith Hospital, London W12 OHS

A. J. MEARNS, F.R.C.S., Registrar in Cardiothoracic Surgery

\section{Case Histories}

CASE 1

A 50-year-old woman complained of weight loss, left chest pain, and occasional haemoptysis for 11 months. On admission to hospital signs of left lower lobe pneumonia were present. After seven days' treatment bronchoscopy and pleural biopsy were performed. The bronchoscopy showed a stenosis of the left lower lobe bronchus, and a biopsy specimen was taken. A pleural biopsy was attempted through the seventh intercostal space in the posterior axillary line.

That evening she complained of pain in the left chest and shoulder. The abdomen was soft and no tenderness was elicited. The blood pressure was $110 / 70 \mathrm{~mm} / \mathrm{Hg}$. A few hours later she was pale, sweating, and had abdominal pain. The abdomen was distended and bowel sounds were absent. The blood pressure was $70 / 0 \mathrm{~mm} / \mathrm{Hg}$. Blood and plasma transfusions were started, and the blood pressure rose to $110 / 70 \mathrm{~mm} / \mathrm{Hg}$; three more bottles of blood were given during the night.

At laparotomy there was $750 \mathrm{ml}$ of free blood in the peritoneal cavity, and a bleeding spleen was removed. Multiple secondary deposits in the liver were noted. Biopsy of the bronchus and liver deposits showed oat cell carcinoma, and the patient died of carcinomatosis three months later. Examination of the spleen showed a subcapsular haematoma with rupture near the upper pole on its diaphragmatic aspect and a 1.4-cm track passing into the pulp at this site.

CASE 2

A 33-year-old woman was admitted to hospital with tiredness, ankle oedema, and haemoptysis. There were clinical signs of rheumatic mitral stenosis. She was taking $0 \cdot 25 \mathrm{mg}$ digoxin twice a day, $40 \mathrm{mg}$ frusemide (Lasix) daily, and warfarin.

A chest radiograph showed signs of pulmonary venous hyper- 